DOI https://doi.org/10.30525/978-9934-588-90-7-86

\title{
СПЕЦКУРС ЯК СКЛАДОВА МЕТОДИЧНОЇ ПІДГОТОВКИ МАЙБУТНІХ ВИКЛАДАЧІВ ІНОЗЕМНОЇ МОВИ
}

\author{
Осова О. О. \\ доктор педагогічних наук, доцент, \\ дочент кафедри іноземної філології \\ Комунальний заклад «Харківська гуманітарно-педагогічна академія» \\ Харківської обласної ради \\ м. Харків, Україна
}

Основною метою сучасної професійної освіти $\epsilon$ підготовка висококваліфікованих кадрів, здатних до продуктивної праці в умовах високих світових стандартів, ініціювання інноваційних змін, самостійного розвитку та самовдосконалення. Соціальне замовлення на викладачів іноземної мови, які не тільки володіють комплексом професійно-педагогічних знань та умінь, але й мають відповідно сформовані навички soft-skills, потребує оновлення існуючих підходів до їхньої методичної підготовки.

У багатьох психолого-педагогічних дослідженнях розкриваються різні аспекти формування методичної компетентності майбутніх учителів іноземної мови. Теоретико-методичні засади формування методичної компетентності майбутніх учителів висвітлюються в численних педагогічних працях науковців (М. Другова, С. Роман, О. Кміть, О. Тарнопольський та ін.). Суттєвим внеском у розробку проблеми формування методичної компетентності майбутніх учителів англійської мови стали дослідження О. Бігич, у яких авторка надає чітке визначення методичної компетентності вчителя іноземної мови, як «сукупності методичних знань, навичок і вмінь та індивідуальних, суб'єктних й особистісних якостей» [1, с. 25], що забезпечують ефективність іншомовної освіти. Однак проблема методичної підготовки майбутніх викладачів іноземної мови вивчена недостатньо.

Згідно 3 контекстним підходом, методичні вміння майбутніх викладачів іноземної мови формуються у процесі організації навчальнопрофесійної діяльності, під час якої «контекст змісту навчання ніби зливається з майбутньою професійною діяльністю» [2, с. 15]. 3 огляду на зазначене, у нашому дослідженні основна увага зосереджена на особливостях методичної підготовки студентів спеціальності «014.02 Середня освіта. Мова і література (Англійська)» як складової їх 
професійно-педагогічної компетентності під час вивчення спецкурсу «нноваційні підходи до викладання іноземної мови у вищій школі».

Наявність спецкурсів у загальній структурі навчання закладів вищої освіти надає широкі можливості для індивідуалізації інтересів, можливостей i здібностей кожного студента. Порівняно 3 іншими дисциплінами, спецкурси характеризуються варіативністю змісту, а також мають чітко виражену змістову, практичну, проєктивну, дослідноекспериментальну та регіональну складові професійно-педагогічної підготовки майбутніх фахівців. Уведення спецкурсів у процес підготовки майбутніх викладачів іноземної мови сприяє також усуненню основної суперечності між широкими освітніми інтересами студентів та недостатнім їх урахуванням у навчальних планах зі спеціальності.

Спецкурс «Інноваційні підходи до викладання іноземної мови у вищій школі», що викладається для студентів-магістрантів Харківської гуманітарно-педагогічної академії, по-перше, сприяє розширенню психолого-педагогічних, лінгводидактичних та методичних знань за рахунок додаткових відомостей, по-друге, забезпечує реалізацію міжпредметних зав'язків зазначених дисциплін, по-третє, сприяє удосконаленню практичних та методичних навичок у контексті інноваційної діяльності майбутніх викладачів іноземної мови.

Метою вивчення спецкурсу $є$ забезпечення методичної підготовки студентів до реалізації професійних функцій викладача іноземної мови. Аналіз змісту програми, анкетування та опитування студентів, які вже мали певний досвід викладання іноземної мови у закладах освіти, або отримали його під час педагогічної практики, дозволили виявити певні протиріччя між наявністю базових знань 3 дисциплін професійнопедагогічного циклу та недостатньо сформованими вміннями використання інноваційних методик викладання іноземної мови у майбутній професійно-педагогічній діяльності. 3 огляду на це, програма спецкурсу окреслюється змістом даної тематики та охоплює чотири модулі. В результаті вивчення дисципліни майбутні викладачі іноземної мови повинні знати суть і загальну характеристику інноваційних технологій навчання іноземних мов; різновиди інноваційних технологій навчання іноземних мов; витоки становлення та розвиток інноваційних педагогічних технологій навчання іноземних мов; сучасні підходи та методи навчання іноземних мов; особливості інноваційної діяльності викладача іноземної мови; відповідність інноваційних технологій специфіці предмету «іноземна мова» тощо.

В результаті опанування спецкурсу майбутні викладачі іноземної мови повинні вміти: визначати й аналізувати цілі, зміст, принципи, інноваційні методи та прийоми навчання іноземної мови; аналізувати, обирати й творчо використовувати навчально-методичні комплекси 3 
іноземної мови; аналізувати, обирати й ефективно використовувати вправи різних типів і видів; формувати у студентів мовну, мовленнєву і соціокультурну компетенції; використовувати у процесі формування іншомовної комунікативної компетенції інноваційні методичні технології; оцінювати рівень сформованості усіх складників іншомовної комунікативної компетенції; планувати й реалізовувати різні форми організації інноваційної освітньої діяльності студентів тощо.

Під час розробки програми спецкурсу враховувалися можливості матеріально-технічнічної бази та створення відповідного дидактичного супроводу; обрано методи засвоєння змісту 3 превалюванням інтерактивних методик та проєктних видів роботи, проблемних та ситуативних мовленнєвих завдань, максимально наближених до методичної діяльності у межах майбутньої професійно-педагогічної. Основними формами викладення теоретичного матеріалу було обрано інтерактивні лекції, лекції-дискусії, проблемні лекції тощо. Процесуальною основою семінарських занять було запровадження широкого спектру діалогових технологій, технології гейміфікації, кооперативного навчання тощо. Визначено основні види освітніх продуктів (твір-роздум «Я - майбутній викладач-інноватор!», «Словник інноваційної термінології з методики викладання іноземної мови», «Методичне портфоліо студента», «Скарбничка інноваційних методів викладання іноземної мови» тощо), які студенти повинні презентувати як результат опанування спецкурсу, а також визначено критерії оцінювання знань [3].

Результати опитування студентів після вивчення спецкурсу, вивчення спостережень за поводженням студентів під час педагогічної практики, аналіз зрізів контрольних робіт дозволяє стверджувати про підвищення рівня теоретичної підготовки студентів у галузі методики викладання іноземної мови, систематизації знань інноваційних методів навчання іноземних мов, їх видів та класифікацій, посилення методичної підготовки студентів під час проведення залікових занять 3 переддипломної практики.

\section{Література:}

1. Бігич О. Б. Теорія і практика формування методичної компетенції вчителя іноземної мови початкової школи : Навчальний посібник / О. Б. Бігич. К. Ленвіт, 2006. 200 с.

2. Вербицкий А. А. Контекстное обучение и становление новой образовательной парадигмы. Жуковский; МИМ «Линк», 2000. 41 с.

3. Осова О.О. Дидактичні засади навчання іноземних мов студентів філологічних спеціальностей із застосуванням технологічних інновацій: автореф. дис. ... д-ра. пед. наук: 13.00.09. Полтава, 2020. 40 с. 